\title{
Water Feasibility Study of Bengawan Solo River for Irrigation: The Need for Technology to Solve Rice Field Pollution in Sragen, Indonesia
}

\section{Setiyo Prajoko \& Riva Ismawati}

Biology Education Department, Faculty of Teacher Training and Education, Universitas Tidar, Magelang, Indonesia

\begin{abstract}
The aims of this study are to determine the feasibility of Bengawan Solo River water for irrigation of rice field in Sragen, Central Java and to find solution to the problem. The data used in this study were obtained from various literatures related to the issues discussed. The collected data were then selected and analyzed with descriptive argumentative. The result indicates that the water quality of Bengawan Solo River has dropped below the water quality standard grade IV according to Government Regulation Number 82 Year 2001. The use of water from this river has caused the quality of rice to decline below the rice quality standard according to Indonesian National Standard (SNI) 01.6128-2008 due to the bioaccumulation of heavy metals on rice crops, i.e. copper (Cu), mercury $(\mathrm{Hg})$, cadmium ( $\mathrm{Cd})$, and Chromium ( $\mathrm{Cr}$ ) exceeded the threshold. Solution proposed to overcome this problem is with counseling programs to farmers conducted by relevant agencies on the use of rice field pollution control technology by physics, chemistry, and biology.
\end{abstract}

\section{Article History}

Received 12 May 2018

Accepted 10 June 2018

\section{Keyword}

Feasibility

Bengawan Solo

Heavy Metals

Quality Standard

Solution

\section{Introduction}

The condition of Bengawan Solo River is currently worrying. Many people have complained about the water condition of this longest and largest river in the island of Java. The results of observations show that, in plain view, the water of Bengawan Solo River looks turbid mixed with mud in the rainy season; while during the dry season, the water is sometimes slightly dark and smelly. Several studies have shown that the water from this river is polluted, and even the content of heavy metals waste is also found. Whereas the Bengawan Solo River is used by some people for their daily needs. The Bengawan Solo River with an average annual rainfall of $2,100 \mathrm{~mm}^{3}$ is a potential water source for management and development efforts of water resources, to meet various needs and requirements such as for domestic consumption, for drinking water and industrial, irrigation, and others (Ministry of Public Works, 2010). 
The development of Solo City into an industrial city has a negative impact on pollution in the river. There are many industries developing in Solo and its surrounding areas that dispose their waste into the river. Batik (traditional clothing) industry that has become the icon of Solo City on the one hand gives positive value for the economy of society but on the other hand also contributes in river pollution. The efforts conducted by the government, social institution, and the society to solve this issue also seem to have been unsuccessful.

Although with the naked eye, the water of Bengawan Solo River is polluted but in some parts of this River Basin, it is still used by people around for everyday purposes. Based on observations to the River, from the City of Solo to Sragen Regency, activities of people who use water from the River such as bathing, washing, fishing, swimming spot for children, and irrigation of agricultural land can be observed. Water utilization of the Bengawan Solo for irrigation occurs in some areas, one of which is in Sragen. In dry season, the agricultural land in Sragen often suffers from water shortages. People who own rice field near the Bengawan Solo River usually take water from the river for irrigation. They do not have the awareness and concern about the importance of the quality of water used for irrigation, whereas, this issue is related to the quality of their crops.

Based on the background, the water condition of Bengawan Solo River is contaminated with heavy metals waste. But there are still people who use it for daily purposes especially farmers for irrigation. This what prompt the water feasibility study of the Bengawan Solo River for irrigation is conducted and also to find the solution.

\section{Materials and Methods}

This article was written using the literature study method. Information is obtained from a variety of literatures and compiled based on the results of the study. Writing is arranged in such a way that they are interrelated between each other and in accordance with the topics covered. The data that used in this paper comes from literatures related to the issues discussed. References that used is taken from books, scientific articles, and newspapers. Then the data analyzed both qualitative and quantitative.

\section{Results and Discussion}

\section{Pollution in Bengawan Solo River}

Various studies have concluded that Bengawan Solo River has been polluted. This river is currently in an unhealthy condition because of the water quality and the environmental support capacity is continuously declining. Pollution can also be seen in the Bengawan Solo River fragment from Solo to Sragen. Utomo et al. (2010) elaborates that the Bengawan Solo River has been heavily polluted with poor water quality because it contains low oxygen, high $\mathrm{CO}_{2}$, high $\mathrm{NH}_{3}$, high $\mathrm{COD}$, high phenol, and high fat oil. In addition, heavy metals concentration in some locations like Kampung Sewu, Bak Kramat, and Tundungan is quite high at $\mathrm{Cr} 0.180-0.375 \mathrm{mg} / \mathrm{L}, \mathrm{Cu} 0.026-0.293 \mathrm{mg} / \mathrm{L}$, and $\mathrm{Zn} 0.515-2.892 \mathrm{mg} / \mathrm{L}$. Heavy metals waste in the form of mercury $(\mathrm{Hg})$ is also found in this River. Riyatun et al. (2004) reveals that mercury level found in the water and also the fish that live freely in Bengawan Solo River is high (0.38-0.64 ppm). It draws concern to the feasibility of the water designation and the fish consumption. Similarly, Astirin et al. (2001) also concludes that all rivers in Surakarta are polluted based on Plankton diversity parameters as the bioindicator.

Meanwhile, BLHD Sragen (local environmental agency) (2012) indicates that the level of water pollution at Bengawan Solo River in Sragen City has exceeded the standard limit of 
water quality. It can be seen from the conditions of BO D $13.5 \mathrm{mg} / \mathrm{L}, \mathrm{COD} 40 \mathrm{mg} / \mathrm{L}$, DO 0.4 $\mathrm{mg} / \mathrm{L}$, phosphate $0.126 \mathrm{mg} / \mathrm{L}$, Fe $0.4647 \mathrm{mg} / \mathrm{L}, \mathrm{Mn} 0.1523 \mathrm{mg} / \mathrm{L}$ ), nitrite $0.261 \mathrm{mg} / \mathrm{L}$, total coliform 920.10/ $100 \mathrm{ml}$, and fecal coliform 170.104/100ml. The data of Bengawan Solo pollution is presented on Table 1.

Table 1. Result of research on pollution of Bengawan Solo River Basin

\begin{tabular}{|c|c|c|}
\hline Researchers & Aspects studied & Information \\
\hline $\begin{array}{l}\text { Astirin OP et al., } \\
2001\end{array}$ & Plankton diversity & Mild to severe pollution \\
\hline $\begin{array}{l}\text { Winarno K. et al., } \\
2000\end{array}$ & $\begin{array}{l}\text { Diversity and wealth } \\
\text { community of Macrobentos }\end{array}$ & Medium-heavy pollution \\
\hline Supriyadi DS, 2002 & $\begin{array}{l}\text { Chemical character and } \\
\text { physical character }\end{array}$ & $\begin{array}{l}\text { Fluctuations in chemical and } \\
\text { physical contents occur }\end{array}$ \\
\hline Sanaky, 2003 & Phytoplankton Diversity & a decline in water quality \\
\hline Riyatun et al., 2003 & Mercury (Hg) & indicated to contaminate with $\mathrm{Hg}$ \\
\hline Utomo et al., 2010 & $\begin{array}{l}\text { BOD, COD, pH, phenol, oil-fat, } \\
\text { ammonia, Cd, Cr, } \mathrm{Zn}, \mathrm{Pb}, \mathrm{Cu} \text {, } \\
\text { and } \mathrm{Zn}\end{array}$ & $\begin{array}{l}\text { Heavily polluted with poor water } \\
\text { quality, contain } \mathrm{Cr}, \mathrm{Cu}, \mathrm{Pb} \text {, and } \mathrm{Zn} \\
\text { contents exceeding grade IV of } \\
\text { water quality standard }\end{array}$ \\
\hline Yuliastuti., 2011 & TSS, DO, BOD, COD, N, P, Fe & A decline in water quality \\
\hline $\begin{array}{l}\text { BLHD (local } \\
\text { environmental } \\
\text { agency), Sragen, } \\
2012\end{array}$ & $\begin{array}{l}\text { Temperature, TSS, TDS, pH, } \\
\text { Nitrate, Ammonia, Cd, Cr, Cu, } \\
\text { Fe, Pb, Mn, } \mathrm{Zn}, \mathrm{Cl} \text {, Nitrite, } \\
\text { Phenol, Ni, Debit, Total } \\
\text { Coliform and Fecal Coliform }\end{array}$ & $\begin{array}{l}\text { There is a decrease in water } \\
\text { quality, some parameters exceed } \\
\text { the standard limit of water quality } \\
\text { grade IV (total coliform and fecal } \\
\text { coliform) }\end{array}$ \\
\hline Astuti et al., 2014 & $\begin{array}{l}\text { Analysis of } \mathrm{Pb} \text {, on White Shrimp } \\
\text { in Bone River (Bengawan Solo } \\
\text { Watershed) }\end{array}$ & $\begin{array}{l}\mathrm{Pb} \text { content in white Shrimp is } \\
\text { found }\end{array}$ \\
\hline Setyarini et al., 2016 & $\begin{array}{l}\mathrm{Cu}, \mathrm{Cd}, \mathrm{Pb} \text {, on broom fish in } \\
\text { solo bengawan river }\end{array}$ & $\begin{array}{l}\text { The content of } \mathrm{Cu}, \mathrm{Cd}, \mathrm{Pb} \text { on pleco } \\
\text { fish exceeds the limit due to the } \\
\text { polluted environment. }\end{array}$ \\
\hline
\end{tabular}

According to the Indonesian Government Regulation No. 82 Year 2001, water quality standards classified based on the parameters of physics, chemistry, and biology are as follows: (a) Water quality grade 1, water that can be utilized for drinking water service and/or other usages that require similar water quality to the utilization; (b) Grade 2, water that may be used for recreational water facilities, cultivation of freshwater fish, livestock, water to irrigate crops and / or other designations that require the same water quality as those usages; (c) Grade 3, water which designation may be used for the cultivation of freshwater fish, livestock, water for cropping, and / or other purposes that require the same water quality to those designations; (d) Grade 4, water that may be used for irrigation, cropping, and / or other designations that require the same water quality as that purposes.

Under the government regulation, it is clearly stated that minimum water quality standard for irrigation is grade 4. However, based on research results, especially in 2012, clearly show that the water quality of the Solo River is below grade IV of water quality standard based on total coliform, fecal coliform, and COD parameters. In addition, heavy metals waste in the river water that exceeds threshold of water quality standard class IV is 
also discovered. The presence of mercury content that exceeds grade IV of water quality standard threshold. A research by Utomo also shows that the content of heavy metals $\mathrm{Cr}, \mathrm{Cu}$, $\mathrm{Pb}$, and $\mathrm{Zn}$ are high enough. Thus, water of Bengawan Solo River is no longer feasible to be used for irrigation.

Quality of Rice Harvest from rice fields along Bengawan Solo River Basin in Sragen Regency

The quality of rice crops is important to note, not only the quantity considering the role of this plant as a staple food source. According to the Directorate General of processing and marketing of agricultural products on rice quality standards based on SNI (Indonesia National Standard) No.01.6128 -2008, rice is classified into 5 grades of quality; namely I, II, III, IV, and V. General terms of rice are: 1) Pest, disease free, 2) Free of musty odor, sour, or other unknown odors, 3) Free of bran mixture, and 4) Free of chemical substances that endanger consumers. While, the minimum specific terms rice are included in quality $\mathrm{V}$. The parameters of rice quality $V$ including milling degree of at least $85 \%$, moisture at $15 \%$, rice head size of at least $60 \%$, minimum grains intact $35 \%$, broken grains maximum $5 \%$, groat grains maximum of $3 \%$, yellow/damaged grains maximum $5 \%$, maximum $5 \%$ of lime grains, maximum $0.2 \%$ of foreign objects, maximum 3 grains/100 gram, and mixture of other varieties of up to $10 \%$. From the general terms of rice quality standards, rice must be free from chemicals that endanger consumers. Unfortunately, the fact found that there is still rice that contains heavy chemical substances that are harmful to consumers.

Sragen as the second largest rice granary in Central Java utilizes Bengawan Solo River for irrigation. Sragen has a total area of 40129 hectares of rice fields. The fact shows that most of the agricultural land in Sragen is crossed by Bengawan Solo River. Based on survey results, farmers take water from this River for irrigation during the dry season. It impacts on the quality of the crops, whereas, during the dry season, the water volume is small and polluted. It affects the quality of their crops. The results of the laboratory analysis Universitas Sebelas Maret, Surakarta in 2003 and 2004 showed that rice yields along the Bengawan Solo River Basin were contaminated with heavy metal of Cu $0.2 \mathrm{mg} /$ $\mathrm{kg}$. Previously in 2003, a research also found that heavy metals content in rice plants in Gesi Region (an area crossed by Bengawan Solo) were in the forms of $\mathrm{Hg} 0.61 \mathrm{mg} / \mathrm{kg}$, Cd $5.69 \mathrm{mg}$ / kg, Cr 0.67 mg/kg (Suara Merdeka, 2004).

\section{Bioaccumulation of heavy metals in agricultural crops}

According to Kurnia et al. (2009), the entry of pollutants on agricultural land is classified into agricultural and non-agricultural activities. A heavy metal contaminant is defined as a type of metal that has a molecular weight and specific gravity greater than 5 $\mathrm{g} / \mathrm{cm}^{3}$. Types of heavy metals that need special attention are $\mathrm{Hg}, \mathrm{Pb}, \mathrm{Cd}, \mathrm{Cu}, \mathrm{Cr}, \mathrm{Co}$, $\mathrm{Mn}$, and Ni. Pollutants may come from agricultural activities and non-agricultural such as industries and mining. Heavy metals can contaminate rice plants through gradual mechanism.

Raskin et al. (1997) explains the bioaccumulation in plants by Phytoextraction. Heavy metals dissolved in water are in the root environment (rhizosphere). These substances will comppete with elements of nutrients for other plants (macro/microelement) absorbed through the roots (rhizofiltration). Next, accumulation of heavy metals in the roots through the transport system of symplast and apoplast occurs. Then, the heavy metals will spread throughout the other parts of plants. Some types of metals can bind to other elements so as to form a complex of compounds with lower toxic effects on plants. Furthermore, the complex will be brought to the vacuole (Haryanti, 2009). Meanwhile, according to Grant 
(1998), the mechanism of absorption and accumulation of heavy metals by plants can be divided into three sustainable processes, namely absorption by roots, translocation of heavy metals from roots to other parts of plant, and localizing metals on cells and tissues. It aims to keep the metals from inhibiting plant metabolism. In an attempt to prevent metal poisoning of cells, plants have detoxification mechanisms; for example by hoarding metals in certain organs such as roots.

\section{Toxicology of Heavy Metals Waste}

The presence of heavy metals in organisms, both animals and plants that are foods for humans, are very dangerous. The human position at the top of food chain must have become a heavy metals accumulator in large quantities. According to Duruibe et a.l (2007), heavy metals can cause biotoxic to humans biochemically and can cause clinical symptoms of heavy metals poisoning. Sudarmaji et al. (2006) discloses the clinical implications of heavy metals biotoxic for human health including: $\mathrm{Pb}$ poisoning can lead to disturbances in the nervous system, kidneys, reproductive system, and circulatory system; mercury poisoning can lead to minamata disease.; and other symptoms such as cerebral palsy, mental disorders, and libido disorders. Cadmium poisoning can lead to interference with the kidneys, heart, blood vessels, and bone disorders. $\mathrm{Cu}$ toxicity can cause disturbances in the respiratory system, skin, kidneys, and blood vessels. While As toxicity can cause disturbances in the eyes, skin, blood, kidneys, liver, respiratory organs, reproductive system, gastrointestinal, and immune system.

The clinical symptoms of heavy metals toxicity cannot be directly observed at once. This is because the accumulation process takes a significant time. Clinical symptoms will appear when the accumulation in the body has exceeded the threshold.

\section{The Need for Socialization of Rice Fields Pollution Control Technologies}

Solution offered to overcome the problem of poor water quality of Bengawan Solo River, that its use is no longer appropriate for irrigation, can be done through preventive and curative actions. Preventive action is done by preventing farmers from using the river water to irrigate their fields. While curative measures can be done by socializing the use of Rice Field Pollution Control Technologies. After recognizing the technology, furthermore, it is expected that the farmers will apply the technology to reduce the heavy metals content in the water of the Bengawan Solo so that it is safe for irrigation.

\section{Preventive Actions}

Preventive action is a useful action to prevent the use of Bengawan Solo water contaminated by heavy metals for irrigation. Therefore, a regular research on the quality of river water by the authorities is required. Such research should be conducted to coincide with the growing season in the dry season. The results of the research should also be published to farmer groups, especially farmers who have rice fields along the Bengawan Solo. Thus, the coordination between the Local Environmental Agency and Local Agricultural Agency which are responsible to provide counseling to farmer groups is needed. Farmers need to be given insights through extension activities on the dangers of using Bengawan Solo water for irrigation; instead the ground water can be use as the replacement (Pantek Well). Pantek well is a drill well to take deep ground water inside.

Preventive action also needs to be performed in formal education. Students who attend schools around Bengawan Solo River Basin are necessary to develop a scientific attitude, especially the attitude of environmental care. Prajoko (2017) suggests that 
it is important to develop a scientific attitude at schools in order to form a scientific attitude culture since early age. So, the attitude of environmental care as a manifestation of scientific attitude will be formed early on. Thus, it needs to develop teaching instruments that are based on environmental insights, especially pollution at Bengawan Solo River, to students as early preventive efforts. Purnomo et al. (2013) uses a module of research on the pollution of the Pepe River (tributary of Bengawan Solo) as the material source of Biology learning on environmental pollution. The results showed that the use of the module is effective for improving Biology learning in that specific material. Meanwhile, according to Putri (2012), the development of Biology learning instruments integrated with character is empirically feasible in terms of concept mastery as well as in the improvement of character education of environmental care.

\section{Curative Actions}

Curative action is an action to reduce the heavy metals content contained in the water of the Bengawan Solo River before being used for irrigation. This action can be done by developing pollution control technologies for rice fields by chemical, physics, and biology which needs to be socialized to the society. Chemically, replace the chemical fertilizers with organic fertilizers. Natural ingredients such as organic and inorganic fertilizers, manures, and limes can improve the quality of the plant. Nurjaya (2003) conducted a research in a greenhouse using zeolite, manure, ash husk, and carbon to absorb more $\mathrm{Pb}$ and $\mathrm{Cd}$ from rice fields in Tegal Regency, Central Java, which are planted with garlic. The results showed that ash husk was able to absorb $\mathrm{Pb}$ and $\mathrm{Cd}$ from the soil with more ameliorant, both by leaves and tubers. According to Kurnia (2009), control of agricultural land pollution in chemical is relatively more expensive. The purpose of chemical solving is only to reduce or minimize the impact caused by pollution, because to completely eliminate the pollution impact is difficult.

The solving by physics is done in order the influence of heavy metals contained in the soil is reduced. This can be done by heating and absorption techniques using active charcoal, zeolite and bentonite, drainage techniques, and agricultural waste (Endrawanto \& Winarno, 1996). The use of agricultural waste such as rice husk is also effective to absorb heavy metals. According to Nurhasni et al. (2010), the optimum conditions of absorption are $\mathrm{pH} 5$ for $\mathrm{Cd}$, and pH 6 for $\mathrm{Cr}$, the concentration of metal ions $20 \mathrm{mg} / \mathrm{L}$, and the duration of heating 2.5 hours. The efficiency of absorption in the multi components waste water for $\mathrm{Cd}$ is $70.42 \%$, while for $\mathrm{Cr}$ is $71.55 \%$. Absorption of cadmium and chromium metal ions under optimum conditions applied to chemical laboratory waste water of Syarif Hidayatullah Islamic State University of Jakarta has a respective absorption efficiency of $66.45 \%$ for Cd and $49.29 \%$ for $\mathrm{Cr}$.

Biologically is by phytoremediation using Mendong Plant, Water Hyacinth, and Rice Field Grass, or other plants that have the potential to become hyperacumulator; while by bioremediation using microorganisms. Phytoremediation and bioremediation are mechanisms of heavy metals absorption by biological agents of either plants or microorganisms. Basically, before the polluted river water is used for irrigation, the heavy metals content should be reduced so that the levels do not exceed the specified threshold.

\section{Phytoremediation}

Phytoremediation is defined as leaching of pollutant which is mediated by plants, including trees, grasses, and aquatic plants. Leaching can be translated as destruction, 
inactivation, or immobilization of pollutants to harmless forms Chaney et al. (1995). There are several strategies of plant performing phytoremediation. The strategies are based on the ability to accumulate contaminants (phytoextraction) or on the ability to absorb and transpire water from within the soil (creation of hydraulic barriers). The ability of roots to absorb contaminants from groundwater (rhizofiltration) and the plants' ability in metabolizing contaminants within the tissues (phytotransformation) are also used in phytoremediation strategies. Phytoremediation is also based on the ability of plants to stimulate biodegradation activity by microbes associated with roots (phytostimulation), and immobilization of contaminants in the soil by exudates of roots (phytostabilization), and the ability of plants to absorb large quantities of metals from the soil and is economically used to remediate problematic soil (phytomining) (Chaney et al., 1995). In addition to mendong plants, rice field grass, and water hyacinth, the following are plant species that have the potential as a hyperaccumulator.

Table 2. Types of Plants Potentially as Hyperacumulators

\begin{tabular}{ll}
\hline Contaminant Type & \multicolumn{1}{c}{ Plant } \\
\hline Zn (zink) & Thlaspi caerulescens, T. calaminare, Sambucus, Rumex \\
Cd (cadmium) & Thla spi caerulescens, Sambucus, Rumex, Mimulus guttatus, Lolium \\
& miscanthus \\
Pb (plumbum) & Lolium miscanthus, Thlaspi rotundifolium \\
Co (cobalt) & Agrotis gigantea, Haumani astrum robertii, Mimulusguttatus \\
$\mathrm{Cu}$ (kuprum) & Aeolanthus biformifolius, Lolium miscanthus \\
$\mathrm{Mn}$ (manganese) & Alyxia rubricaulis \\
$\mathrm{Ni}$ (nickel) & Alyssum berkolinii, A. lesbiacum, Berkheya coddi, Hybanthus \\
& flor ibundhus, Thlaspi goesingense, T. montanum, Senesio \\
$\mathrm{Cs}$ (cesium) & coronatus, Lol ium miscanthus, Phyllanthus serpentinus \\
As (arsenic) & Amaranthus retroflexus \\
$\mathrm{Se}$ (selenium) & Astragalus racemosus \\
Fe (ferum) & Poaceae \\
$\mathrm{Hg}$ (merkurium) & Arabidopsis thaliana \\
Salinity & Attriplex spp., Halosarcia spp., Enneapogon spp. \\
Crude oil & Euphorbia, Cetraria, Amaranthus retroflexus. \\
\hline
\end{tabular}

Source: Hidayati (2005)

The heavy metals absorbed by plants will further, the toxic effects, be reduced by the plants. Pulford \& Watson (2002) describe the mechanisms for reducing toxic effects can be done by combining metals absorbed by the plants with substances contained in the plant. Then, the result of the merger will be brought into the vacuole in plant cells to be stored.

\section{Bioremediation}

Bioremediation is the use of microorganisms to reduce pollutant in the environment. When bioremediation is conducting, enzymes produced by microorganisms modify toxic pollutants by altering the chemical structure of the pollutants and this is what so called as biotransformation. In many cases, biotransformation leads to biodegradation where toxic 
pollutants are degraded; the structure becomes no longer complex and thus ultimately becomes harmless and nontoxic metabolites.

Several types of bacteria, such as Pseudomonas, Thiobacillus, Bacillus, and nitrogenfixing bacteria are reported to be able to accumulate heavy metals. Microorganisms have a variety of ways of absorbing toxic metals and several mechanisms are known at the molecular level. Resistance to metals is usually encoded by plasmids contained in the bacteria. Skladany (1993) reveals that plasmids that become efflux path way for As and Cd exists in certain bacteria and is able to differentiate the absorption paths for $\mathrm{P}$ and $\mathrm{Mn}$, through $\mathrm{As}$ and $\mathrm{Cd}$ which each enters into the cells. Some metals and their components are target in the biotransformation that may increase or decrease toxic. The efflux path ways for metals such as $\mathrm{Cd}$ and Ion $\mathrm{Hg}^{2+}$ are detoxified by metal translocation penetrating via intracellular reductase. The alkylation process of $\mathrm{Pb}$ and $\mathrm{As}$ components by prokaryotic and eukaryotic microbes may increase the toxic potential.

In Indonesia, the use of bacteria as bioremediator to accumulate heavy metals Bacillus sp., has been tested on rice fields contaminated by industrial waste. Kurnia (2009) explains that the success of reduction of heavy metals pollution by microbes accumulating heavy metals is influenced by its superiority in accumulating heavy metals. Each type of microbe has different characters to be able to live in the same environment. Microorganisms capable of living at relatively higher concentrations of metals than predetermined environmental quality standards may be used as reference in the use of such microbes in reducing pollution, both on farmland and in aquatic body, in accordance with the high content of heavy metals within the contaminated environments. The use of microbes is expected to improve the health of farmers and the benefits of farming, so as to accelerate poverty alleviation. Utilization of microbes accumulating heavy metals does not cause soil contamination.

\section{Conclusions}

Based on the study that has been done, it can be concluded that the water quality of Bengawan Solo River has dropped below the water standard grade IV especially during the dry season. So it is no longer appropriate allocation for irrigation. The use of water for irrigation from the River is the cause of the declining quality of rice harvest in Sragen Regency because there is a bioaccumulation of heavy metals on rice grains. Preventive action can be done to prevent pollution of rice fields by conducting socialization to Farmers Group through counseling activities. To develop teaching instruments based on environmental insight is necessary for students as an early socialization effort. Curative action can be done with the use of pollution control technology on rice fields either by physics, chemistry, and biology.

\section{References}

Astirin, O.P., Setyawan, A.D. \& Harini M. 2001. Plankton Diversity as a River Quality Indicator in Surakarta City. Biodiversitas, 3 (2): 236-241.

Astuti, T. D., Kadir, S., \& Boekoesoe, L. 2014. Analysis of Lead Metal Pollution (Pb) on White Shrimp (Litopenaeus vannamei) in Bone River (Doctoral dissertation, UNG).

Environment Agency of Sragen Regency. 2012. Water Laboratory Test results of Bengawan Solo River in Sragen.

Chaney, R. L., Angle, J. S., Baker, A. J., \& Li, Y. M. 1998. U.S. Patent No. 5,711,784. Washington, DC: U.S. Patent and Trademark Office. 
Duruibe, J. O., Ogwuegbu, M. O. C., \& Egwurugwu, J. N. 2007. Heavy metal pollution and human biotoxic effects. International Journal of physical sciences, 2(5), 112118.Endrawanto dan H. Winarno. 1996. Process Physical and chemical waste processing. Proceedings of Training and Workshop on the Role of Bioremidiation in Environmental Management . LIPI-BPPT-HSF.

Grant, C.A., W.T. Buckley, L.D. Bailey, and F. Selles, 1998. Cadmium accumulation in crops. Ca. J. Plant Sci. 78: 1-17.

Haryanti, S., Nintya Setiari, Rini Budi Hastuti, Endah Dwi Hastuti, dan Yulita Nurchayati. 2009. Physiological Response and Anatomy of Water Hyacinth (Eichornia crassipes) in Various Irrigated Waters. Jurnal Penelitian Sains dan Teknologi. Vol 10. No.1: 3040

Hidayati, N. 2005. Phytoremediation and Potential Hiperakumulator. Hayati, 12 (1): 35-40.

Ministry of Public Works. 2010. Decree of the Minister of Public Workers on the Water Resources Management Pattern of the Bengawan Solo River Region.

Kurnia, U., Suganda, H., Saraswati, R. \& Nurjaya. 2009. Rice Field Pollution Control Technologies. (online), (http://gobookee.org), accessed September 10, 2013.

Nurjaya. 2003. Status of C-organic wetland in Indonesia. Congress of Indonesian Soil Science Association (HITI) at Andalas University, Padang.

Nurhasni, Hendrawati dan Saniyyah N. 2010. Absorption of Ion Metal $\mathrm{Cd}$ and $\mathrm{Cr}$ in Wastewater Using Rice Husk. Thesis article: Chemistry Study Program FST UNI Syarif Hidayatullah, Jakarta.

Prajoko, S. 2017. Development of Problem-Based Science Practicum Learning Tools Using Recycled Materials to Improve Critical Thinking Skills, Science Process Skills, and Scientific Attitudes to Open University Students with Different Academic Capabilities. DISERTASI and TESIS Graduate Program UM. Retrieved from http://karya-ilmiah.um.ac.id/index.php/disertasi/article/view/56197

Presiden RI. 2001. RI Government Regulation no. 82 of 2001 on the management of water quality and control of water pollution.

Pulford I.D., Watson C. 2002. Phytoremediation of Heavy Metal-Contamined Land by Trees. ELSEVIER Environmental International, 29: 529-540.

Purnomo D., Indrowati M., dan Karyanto P. 2013. Effect of Using Module Result of Pollution Research in Pepe Surakarta River as Biology Learning Element of Environmental Pollution Discussion to Student Learning Result. Pendidikan Biologi, 5 (1): 56-69. [in Indonesia]

Putri R.A. 2012. Development of Integrated Biology Learning Tool Character and Material of Environmental Education (PLH). BioEdu, 1 (3): 32-38.

Raskin, I. Smith, R.D. \& Salt, D.E. 1997. Phytoremediation of metals: using plants to remove pollutants from the environment. Curent Opinion in Biotecnology, 8: 221-226.

Ismawati, R., \& Prajoko, S. (2018). Kitosan-Zeolit Composite: Potential for Utilization as CO2 Adsorbent. Al-Kimia, 6(1). Retrieved from http://journal.uin-alauddin.ac.id/index. php/al-kimia/article/view/4645 [in Indonesia]

Riyatun, Sugiarti, S.W., Wijaya, A.D., Sardjono Y. 2004. Indication of Mercury Pollution (Hg) in Bengawan Solo River. BioSMART, 6 (1): 138-142.

Sanaky, A. 2003. Phytoplankton Community Structure And Its Relation to Physics and Chemical Parameters of the waters of the Estuary of Bengawan Solo River, Ujung Pangkah, gresik, East Java. Unpublished thesis. Bogor: IPB. [in Indonesia] 
Setyarini, R. E., Astuti, D., \& Ambarwati, A. 2016. The Investigation of Heavy Metal Content $(\mathrm{Cu}, \mathrm{Cd}, \mathrm{Pb})$ in Sapu-Sapu Fish (Hypostomus plecostomus) in Bengawan Solo River. In Forum Geografi. 19 (2) : 103-114).

Skladany, G. J., \& Metting Jr, F. B. 1993. Bioremediation of contaminated soil. Soil microbial ecology: Applications in agricultural and environmental management, 483-513.

Suara merdeka.com. 2004. Rice Watershed Paddy Field, Appealed to Use Water Bengwan Solo. (online), (http://suaramerdeka.com), accessed 29 October 2013 [in Indonesia].

Sudarmaji, Mukono, J. \& Corie I.P. 2006. Heavy Metal Toxicology and Its Impact on Health, 2 (2): 129-142.

Supriyadi D.S. 2002. Conditions of Muara Water Based on Physical and Chemical Parameters in Estuary of Solo Ujung Pangkah Village of Gresik, East Java. Unpublished thesis. Bogor: IPB [in Indonesia]

Utomo, A.D., Ridho M.R. Edward S. \& Putranto, D.A. 2010. Pollution on the Solo River Solo between Solo and Sragen, Central Java. Bawal, 3 (1):25-32 [in Indonesia]

Winarno K., Astirin, O.P. \& Setyawan, D.S. 2000. Monitoring of Jabung Swamp Water Quality based on Bentos Community's Diversity and Wealth. BioSMART, 2 (1): 40-46 [in Indonesia]

Yuliastuti, E. 2011. Study of Water Quality of Karanganyar River in Efforts to Control Water Pollution. Thesis not published. Semarang: Undip [in Indonesia]. 